\title{
Anna Ball and Karim Mattar, eds. The Edinburgh Companion to the Postcolonial Middle East.
}

Ruth Abou Rached

\section{OpenEdition}

1 Journals

Electronic version

URL: https://journals.openedition.org/ces/2098

DOI: 10.4000/ces.2098

ISSN: 2534-6695

Publisher

SEPC (Société d'études des pays du Commonwealth)

\section{Electronic reference}

Ruth Abou Rached, "Anna Ball and Karim Mattar, eds. The Edinburgh Companion to the Postcolonial Middle East.", Commonwealth Essays and Studies [Online], 42.2 I 2020, Online since 30 September 2020, connection on 27 January 2022. URL: http://journals.openedition.org/ces/2098 ; DOI: https://doi.org/ $10.4000 /$ ces. 2098

This text was automatically generated on 27 January 2022

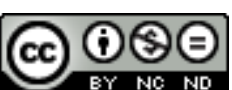

Commonwealth Essays and Studies is licensed under a Licence Creative Commons Attribution - Pas d'Utilisation Commerciale - Pas de Modification 4.0 International. 


\title{
Anna Ball and Karim Mattar, eds. The Edinburgh Companion to the Postcolonial Middle East.
}

\author{
Ruth Abou Rached
}

\section{REFERENCES}

Edinburgh: Edinburgh University Press. 522 p. ISBN: 978147442 7685. £150.00.

1 The two words "postcolonial" and "Middle East" are recurrent, often charged terms of debate in many fields of inquiry and their points of intersection are numerous. One question is how postcolonial studies - the engagement with experiences of colonialism in its past and present forms - meaningfully relates to the Middle East as a new crucial area of critical concern. Other key questions focus on why the study of the Middle East appears at times incoherent or disparate in contexts of postcolonial studies. The Edinburgh Companion to the Postcolonial Middle East edited by Anna Ball and Karim Mattar does not set out to provide any ready-made answers to these questions. What it does aim to do, however, is help readers navigate such debates by bringing together, for the first time in one volume, a large host of established scholars, artists, and writers who share their reflections on how the kaleidoscopic local and global scopes of the Middle East could be conceptualized in the field of postcolonial studies.

2 The volume is composed of 24 chapters and is divided into four sections. The first section, "Introduction," maps out the postcolonial Middle East as a nascent sub-field. The introduction by Anna Ball and Karim Mattar provides a stimulating overview of the field and is followed by two chapters and two interviews. Karim Mattar revisits readings of Edward Said that downplayed his experience of exile from Palestine to demonstrate how future interrogations of postcolonial studies "as institution" (24) need to take greater account of Said's relation to Palestine and the Middle East. Wail Hassan interrogates the limits of Western intellectual histories and calls for the fields 
of Arabic literature and postcolonial studies to be completely re-appraised within more expansive, non-dualistic frames of analysis. The two interviews, between Anna Ball and Ahdaf Soueif and between Karim Mattar and Sinaan Antoon, concern the lived politics of writing and the critical linkages between cultural exchange, creativity, and hopes for justice.

The second section, "The Colonial Encounter: Discourses of Imperialism and AntiImperialism," focuses on the diverse realities of empire, subalternity, and Orientalism as mosaic-like pasts shaping the many, complex lived presents. Through his illuminating readings of Orhan Pamuk's novels The White Castle and My Name is Red, Erdağ Göknar argues that the reflections of the Ottoman Empire that Pamuk ciphered into his story-making can be read as complex interrogations of the premises of modernity in Turkey today. Ella Shohat's analysis of nineteenth-century representations of Jewish and Muslim women of the Middle East shows that one of the deepest rifts generated by Orientalism is the bifurcation of identities in the Middle East, with reverberations to the present day. Other contributors share key theories and alternative methodologies by which histories of Empire can be reconfigured. Drawing from Subaltern Studies, Juan Cole incisively debates how histories of marginalized identities of the Middle East have been attended to in current scholarship. Stephen Morton explains how hidden histories of violence can be discerned in fictional archives, taking literary representations of British colonial brutality towards Egyptians in 1906 as a case study. Wen-Chin Ouyang shows how colonial visions of Egypt's history can be challenged by drawing on alternative sources, such as Taha Hussein's writings on literary Egypt as part of a cosmopolitan Mediterranean world. Marilyn Booth retells the stories of women's activism in Egypt as debated in Arabic periodicals of the 1890s, a key decade of the Middle East which has so far been overlooked.

4 The third section, "States of Post/Coloniality: Politics, Religion, Gender, Sexuality," moves to the impact of colonial and postcolonial imaginaries on state and society formations in the Middle East. Réda Bensmaïa's reading of L'Invention du désert by Taher Djaout suggests that the imaginary functions as a repository with the capacity to interrogate memories (of Algeria) which, in his view, are still framed by the colonial narrative. Despite much Palestinian literature expressing despair in post-millennial Palestine, Salih Hassan's chapter reiterates that the power to write and read an "impossible" imaginary is something not to be underestimated, a point supported by Anna Ball in her chapter on 1980s Palestine solidarity literature and Lindsey Moore's on the teaching of Queer textualities in relation to Huda Barakat's The Stone of Laughter, a novel about masculinities and war in Lebanon. Not all cultural production of the postcolonial Middle East is presented in this section as occupying solely the realm of the imaginary. Sadia Abbas' chapter on the aesthetics of destruction staged by Daesh warns us against the dangers of glamourized counter-colonial politics of annihilation. Anastasia Valassopoulos's chapter on Arab women's engagement with anti-colonial practice and discourse is a very salient reminder that much of the histories of Arab women's activism is now only discernable in cultural productions such as film and literary writing.

5 The final section, entitled "The Post/colonial Present: Crisis and Engagement in Global Context," situates postcolonialism as a "medium for critical thinking in the face of violent political realities" (5) in current contexts specific to the Middle East. Tahia Abdel Nasser explores how Najla Said and Hisham Matar write their memories of failed 
returns to Palestine and Libya in English, a language intertwined with the violence of colonial and postcolonial histories of both lands. Ikram Masmoudi addresses representations of liminal Iraqi identities in post-2003 Iraqi war literature and why the reading of this literature is an intensely political act. Laetitia Nanquette's chapter on the Iranian literary blogosphere emerging across varying mechanisms of state censorship interrogates facile notions of imagined communities constituted via global networks. As Caroline Rooney's thoughtful reflections on the politics of writing the "Arab Spring" as an "event" remind us, relating to the postcolonial Middle East requires openness to lived, rather than assumed, realities. It is fitting then that the final two chapters centre on lived experiences of current crises in the Middle East. In her overview of the political situation in Syria, miriam cooke argues that innovative creative engagements of Syrian activist-artists augur an era where new understandings of political representation could emerge. ${ }^{1}$ Anna Ball's chapter on the changing representations of "the Middle Eastern refugee child" in Europe invites us to consider and study the experiences of children and learn from them new creative ways to represent the experience of forced migration.

of course, not all societies, histories and languages of key importance in the Middle East can be covered in one volume of work. Connecting the volume more explicitly to critical interventions within the various fields of Religious Studies would perhaps have broadened its already rich, expansive agenda - as would have more detailed discussions on digital humanities, linguistics, ethnographic and translation studies in relation to the postcolonial Middle East. In view of the volume's clear agenda of opening new conversations, such gaps are invitations to further research. This book is a seminal reference work with great appeal to diverse readerships.

\section{NOTES}

1. Professor mariam cooke prefers her name non-capitalised (see her current profile: https:// scholars.duke.edu/person/mcw).

\section{AUTHORS}

\section{RUTH ABOU RACHED}

Ruth Abou Rached is a postdoctoral researcher for the ERC-project "PalREAD: Country of Words" at the Freie Universität Berlin. Her research interests are Arab women's literature, translation studies, and Arab exilic cultural production. She is editor of New Voices in Translation Studies, published by the International Association for Translation and Intercultural Studies. 